\title{
Influence of Oxygen on Growth, Cytochrome Synthesis and Fermentation Pattern in Propionic Acid Bacteria
}

\author{
By WYTSKE DE VRIES, WILHELMINA M. C. VAN WIJCK-KAPTEIJN \\ AND A. H. STOUTHAMER \\ Microbiology Department, Biological Laboratory, Free University, \\ De Boelelaan 1087, Amsterdam, The Netherlands
}

(Accepted for publication 29 February 1972)

\begin{abstract}
SUMMARY
The influence of oxygen on growth and cytochrome synthesis was investigated in four species of Propionibacterium. After anaerobic growth all species contained cytochrome $b$, cytochrome $a$ or $a_{1}$, cytochrome $a_{2}$ and a carbon monoxide-binding pigment. Cytochrome $b$ functions in an electron transport system from lactate to fumarate since the lactate-fumarate dismutation reaction, unlike lactate oxidation via methylene blue, was strongly inhibited by $2-n$-heptyl-4-hydroxyquinoline- $N$-oxide (HOQNO). No species grew on agar plates under aerobic conditions but all grew in aerated media, though at different rates and with diminished synthesis of all cytochromes. In Propionibacterium freudenreichii and $P$. shermanii, which grew slower under aerobic conditions than $P$. rubrum and $P$. pentosaceum, cytochrome synthesis was more repressed by oxygen. Large amounts of pyruvate accumulated under aerobic conditions whereas acetate, propionate and succinate were not formed. The bacteria are therefore dependent on oxidative phosphorylation for energy under aerobic conditions. For $P$. freudenreichii an $Y_{\mathrm{o}}$ value (g dry wt bacteria/g-atom oxygen taken up) of I 5 was measured, suggesting a $\mathrm{P} / \mathrm{O}$ value of $\mathrm{I}$ to 2 . Absence of cytochrome synthesis resulting in the loss of oxidative phosphorylation may explain the absence of aerobic growth on agar plates.
\end{abstract}

\section{INTRODUCTION}

Propionic acid bacteria produce propionate, acetate and carbon dioxide as major fermentation products from lactate and carbohydrates. Acetate and carbon dioxide are formed from pyruvate by pyruvate dehydrogenase, propionate is formed from pyruvate via methylmalonyl CoA (Allen, Kellermeyer, Stjernholm \& Wood, 1964). The lactate dehydrogenase of Propionibacterium pentosaceum is not linked to NAD but can use fumarate and several redox dyes such as phenazine methosulphate and 2,6-dichlorophenol indophenol as a $\mathbf{H}$-acceptor (Molinari \& Lara, 1960). The fumarate-lactate dismutation reaction has been previously described by Barker \& Lipmann (1944).

Although propionic acid bacteria are anaerobic, they are not very sensitive to oxygen and can grow in aerated media (Breed, Murray \& Smith, 1957; Menon \& Shemin, 1967). Propionibacterium pentosaceum has a conventional citric acid cycle (Delwiche \& Carson, I953) and contains cytochromes $a$ and $b$ and cytochrome oxidase (Chaix \& Fromageot, I 942). The succinate dehydrogenase of this organism is functionally linked to cytochrome $b$ (Lara, 1959). We know of no further data on the aerobic metabolism of propionic acid bacteria.

The present paper deals with the function of cytochromes in propionic acid bacteria and with the influence of oxygen on their growth and metabolism. 


\section{METHODS}

Organisms and growth conditions. The experiments were done with Propionibacterium freudenreichii, $P$. rubrum, $P$. shermanii and $P$. pentosaceum obtained from Ir. F.F.J. Nieuwenhof (Nederlands Instituut voor Zuivelonderzoek, Ede, The Netherlands) and from Ir. J. van der Toorn (Technische Hogeschool, Delft, The Netherlands). They were maintained as stab cultures in the following basal medium with $\mathrm{I} \cdot 5 \%$ agar (Oxoid). The basal medium contained (g/l distilled water): tryptone (Oxoid), 5 ; yeast extract (Oxoid), ${ }_{1} 0 ; \mathrm{KH}_{2} \mathrm{PO}_{4}, 0.5$; $\mathrm{MnSO}_{4}, 0.0 \mathrm{I} ; 70 \%$ sodium lactate solution, $\mathrm{I} 5 ; \mathrm{pH} 6.6$. For some experiments sodium lactate was omitted from the medium. Cultures were grown at $30^{\circ} \mathrm{C}$ under pure nitrogen in McIntosh anaerobic jars.

For growth experiments cultures were grown in the Microferm Laboratory Fermenter (Model MF 102 or MF 107, New Brunswick Scientific Co., New Brunswick, New York, U.S.A.), sparged with nitrogen (I $1 / 1 \mathrm{medium} / \mathrm{min}$ ) and agitated at $100 \mathrm{rev} . / \mathrm{min}$. For aerobic cultures, an anaerobic culture was inoculated into fresh medium to an extinction (at $660 \mathrm{~nm}$ ) of about 0.10 and then aerated with $\mathrm{I} 1$ air $/ 1 \mathrm{medium} / \mathrm{min}$ and agitated at $300 \mathrm{rev} / \mathrm{min}$. Control of $\mathrm{pH}$ was unnecessary as the $\mathrm{pH}$ did not change more than $\mathrm{O} \cdot \mathrm{I}$ unit during both anaerobic and aerobic growth $(\mathrm{pH}$ anaerobic culture $6.5 ; \mathrm{pH}$ aerobic culture $6 \cdot 7)$. Growth of cultures was followed turbidimetrically at $660 \mathrm{~nm}$. Dry weights were measured by filtration on membrane filters as described previously (de Vries \& Stouthamer, 1968). In some experiments the dry weight was calculated from the extinction.

Determination of fermentation products, pyruvate, $\alpha$-ketoglutarate and total polysaccharide. Propionate and succinate were measured by gas-liquid chromatography (g.l.c.) using a Varian gas chromatograph, series 1800 (Varian Aerograph, California, U.S.A.), fitted with a flame ionization detector and a $6 \mathrm{ft} \times \frac{1}{8}$ inch stainless-steel column packed with $4 \%$ Reoplex 400 on acid-washed Chromosorb W (80/100 mesh). Reoplex 400 (polypropylene glycol adipate) was obtained from Applied Science Laboratories, Inc., State College, Pennsylvania, U.S.A., Chromosorb W from Johns Manville, New York, New York State, U.S.A. Conditions of chromatography were: $\mathrm{He}$, as carrier gas, $30 \mathrm{ml} / \mathrm{min}$; column oven temperature $\mathrm{I} 45^{\circ} \mathrm{C}$. Succinate was measured as the methyl derivative prepared as described by Cato $e t$ al . (1970). Propionate was measured by direct injection of culture supernatants into the column. Under the conditions mentioned propionate was completely separated from acetate. The propionate and succinate contents were deduced from the peak heights with the aid of a standard curve.

For acetate determination the enzymatic method of Rose, Grunberg-Manago, Korey \& Ochoa (1954), which is based on the colorimetric determination of acetyl phosphate according to Lipmann \& Tuttle (1945), was used in preference to g.l.c. analysis. Pyruvate was determined according to Friedemann \& Haugen (1943). $\alpha$-Ketoglutarate was measured according to the method of Reekers (1964), based on the method of Friedemann \& Haugen (1943). Total polysaccharide in whole cells was determined with the anthrone reagent (Trevelyan \& Harrison, 1952) using glucose as a standard.

Measurement of respiration by bacterial suspensions. For the preparation of bacterial suspensions, cultures were harvested at extinctions between 0.60 and 0.90 and bacteria were washed twice with $0.067 \mathrm{M}-\mathrm{K}_{2} \mathrm{HPO}_{4}-\mathrm{NaOH}$ buffer $(\mathrm{pH} \mathrm{6.8)}$ and resuspended in this buffer to an extinction of 12.5 ( $5 \mathrm{mg}$ dry wt bacteria/ml). Oxygen uptake and carbon dioxide evolution were measured by Warburg manometry. Substrates were added to a final concentration of $0.2 \%$.

Measurement of spectra and determination of cytochrome $b$. Reduced minus oxidized 
difference spectra were recorded between 400 and $700 \mathrm{~nm}$ using an Aminco Chance recording spectrophotometer (American Instrument Co. Inc., Washington, U.S.A.) with a slide wire of full-scale deflexion $0.05,0.1$ or 0.2 extinction units. Cytochrome $b$ was estimated as the extinction increment between the maximum at $562 \mathrm{~nm}$ and the minimum at $578 \mathrm{~nm}$ in the dithionite-reduced minus oxygen-oxidized difference spectrum and its amount calculated from $\varepsilon=17500$ (Deeb \& Hager, 1964). Carbon monoxide difference spectra were measured by bubbling a dithionite-reduced sample with carbon monoxide for $2 \mathrm{~min}$, and comparing this with a similarly reduced sample. In all cases corrections for small deviations in the base line were applied.

Determination of $Y_{\mathrm{o}}$ ( $g$ dry wt bacteria/g-atom of oxygen taken up). Cultures were grown anaerobically in the basal medium without added glucose or lactate. In this medium cultures grew to a maximal extinction of 0.43 . Oxygen consumption in samples of the culture was followed for about $6 \mathrm{~h}$ in Warburg vessels. The increase of dry weight during aerobic growth was calculated from the extinctions of the culture before and after the Warburg experiment. Fermentation products were determined in the supernatant fluids.

Measurement of the lactate-fumarate dismutation reaction and lactate dehydrogenase. Bacteria, suspended in $0.067 \mathrm{M}$-phosphate buffer $(\mathrm{pH} \mathrm{6.8)}$, were disrupted with an ultrasonic disintegrator ( $60 \mathrm{~W}, 20 \mathrm{kHz}$; M.S.E. Ltd, London) for $10 \mathrm{~min}$. The resulting material was centrifuged at $6000 \mathrm{~g}$. Protein was measured by the method of Lowry, Rosebrough, Farr \& Randall (I95I) using bovine serum albumin as a standard. The lactate-fumarate dismutation reaction was measured by the amount of pyruvate formed under nitrogen in an

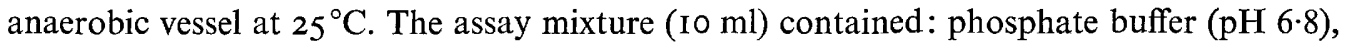
$40 \mathrm{mM}$; sodium fumarate, IO $\mathrm{mM}$; sodium DL-lactate, $25 \mathrm{~mm}$; bacterial extract, 0.3 to $0.5 \mathrm{mg}$ protein $/ \mathrm{ml}$ assay mixture. After Io and $20 \mathrm{~min}, 3.0 \mathrm{ml}$ of the mixture was added to $0.75 \mathrm{ml}$ $10 \%(\mathrm{w} / \mathrm{v})$ trichloroacetic acid. After centrifuging, pyruvate was determined in the supernatant fluid. Lactate dehydrogenase was measured manometrically (oxygen uptake) in a reaction mixture containing: phosphate buffer ( $\mathrm{pH} 6 \cdot 8$ ), $50 \mathrm{~mm}$; sodium DL-lactate, $50 \mathrm{~mm}$; methylene blue, I. $3 \mathrm{~mm}$; and bacterial extract, $0.4 \mathrm{mg}$ protein $/ \mathrm{ml}$ assay mixture. The centre well contained $0^{\circ} \mathrm{I} \mathrm{ml} 4 \mathrm{~N}-\mathrm{KOH}$. Lactate-fumarate dismutase and lactate dehydrogenase were also measured in the presence of $0.1 \mathrm{mM} 2-n$-heptyl-4-hydroxyquinoline- $N$-oxide (HOQNO).

\section{RESULTS}

Oxidation of substrates by suspensions of Propionibacterium freudenreichii

Suspensions of Propionibacterium freudenreichii oxidized $\mathrm{D}(-)$ lactate, $\mathrm{L}(+)$ lactate, pyruvate, acetate and succinate with specific activities ranging from 42 to $5 \mathrm{nmol} \mathrm{O} / \mathrm{mg}$ dry $\mathrm{wt} / \mathrm{min}$. Of $2 \mathrm{I}$ amino acids tested only alanine, cysteine and serine were oxidized with marked activity. In one experiment with lactate in a limiting amount, oxygen uptake and carbon dioxide evolution were followed until they equalled endogeneous rates. Oxygen uptake and carbon dioxide evolution were about $50 \%$ of the amounts needed for complete combustion of lactate. No pyruvate, acetate, succinate, $\alpha$-ketoglutarate or propionate were found in the supernatant fluid. These results indicated that part of the lactate was completely oxidized via the citric acid cycle and the remainder converted to storage products.

\section{Influence of aeration on growth and cytochrome synthesis in propionic acid bacteria}

Propionibacterium freudenreichii grew aerobically much slower than anaerobically (Fig. I $a$ ). After anaerobic growth, cytochrome $b(\alpha$-peak at $562 \mathrm{~nm}, \beta$-peak at $532 \mathrm{~nm}$, Soret peak at $430 \mathrm{~nm})$, cytochrome $a$ or $a_{1}(\alpha$-peak at $600 \mathrm{~nm})$ and cytochrome $a_{2}(\alpha$-peak at $625 \mathrm{~nm})$ 



Fig. I. Influence of aeration on growth $(a)$ and cytochrome synthesis $(b)$ in Propionibacterium freudenreichii. $\bullet$, Anaerobic conditions; $O$, aerobic conditions.

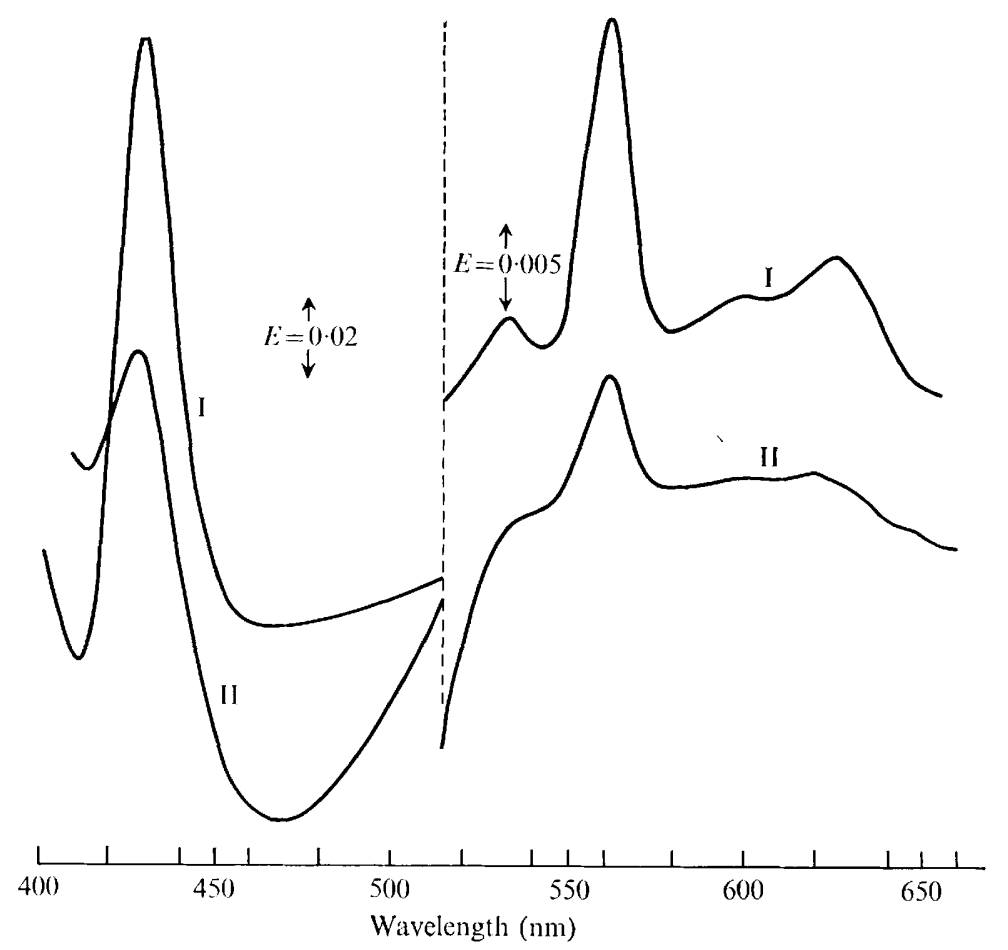

Fig. 2. Reduced minus oxidized difference spectra of Propionibacterium freudenreichii. Suspensions were reduced in the presence of sodium dithionite. Oxidation was carried out with oxygen. I, spectrum of anaerobically grown bacteria; II, spectrum of aerobically grown bacteria. Both suspensions contained $5 \mathrm{mg}$ dry wt bacteria/ml. 


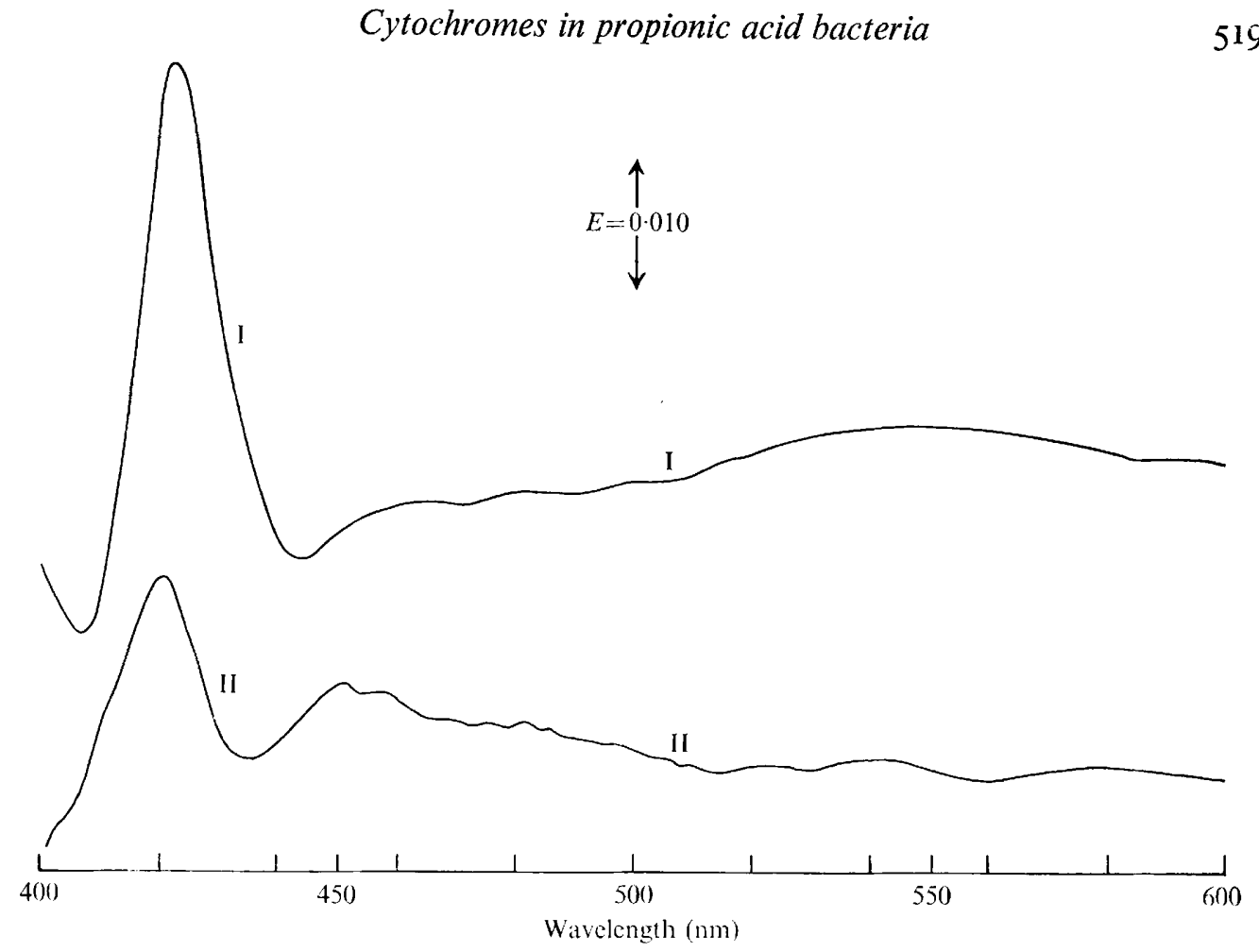

Fig. 3. (Reduced plus CO) minus reduced difference spectra of Propionibacterium freudenreichii. I, spectrum obtained after anaerobic growth; II, spectrum obtained after aerobic growth. Both suspensions contained $5 \mathrm{mg}$ dry wt bacteria/ml.

Table I. Influence of aeration on growth and cytochrome synthesis in propionic acid bacteria

\begin{tabular}{llcc}
\multicolumn{1}{c}{ Organism } & $\begin{array}{c}\text { Growth } \\
\text { condition }\end{array}$ & $\begin{array}{c}\text { Growth rate* } \\
\left(\Delta E_{660} / \mathrm{h}\right)\end{array}$ & $\begin{array}{c}\text { Differential rate of } \\
\text { cytochrome synthesis } \dagger \\
(\mu \mathrm{mol} / \mathrm{g} \text { bacterial dry wt })\end{array}$ \\
Propionibacterium freudenreichii & Anaerobic & 0.050 & 0.23 \\
& Aerobic & 0.013 & 0.01 \\
& Anaerobic & 0.050 & 0.22 \\
$P$. rubrum & Aerobic & 0.013 & 0.01 \\
& Anaerobic & 0.043 & 0.16 \\
$P$. pentosaceum & Aerobic & 0.050 & 0.06 \\
& Anaerobic & 0.044 & 0.25 \\
& Aerobic & 0.067 & 0.05
\end{tabular}

* All organisms grew at an arithmetic rate.

$\uparrow$ With aerobic growth, calculated over first 16 h growth; with anaerobic growth, calculated over the whole period of growth (see Fig. I). Bacterial dry wt calculated from culture densities.

were present (Fig. 2). A minimum at $460 \mathrm{~nm}$ in this spectrum indicates the presence of flavoproteins. After aerobic growth in liquid cultures all cytochromes were greatly diminished (Fig. 2). The same was true for a carbon monoxide-binding pigment which had a peak at $42 \mathrm{Im}$ in the carbon monoxide-difference spectra (Fig. 3). The slight asymmetry of the main band in the latter spectrum may indicate that a small amount of cytochrome $a_{1}$ is present. During anaerobic growth of $P$. freudenreichii cytochrome synthesis parallelled cell 


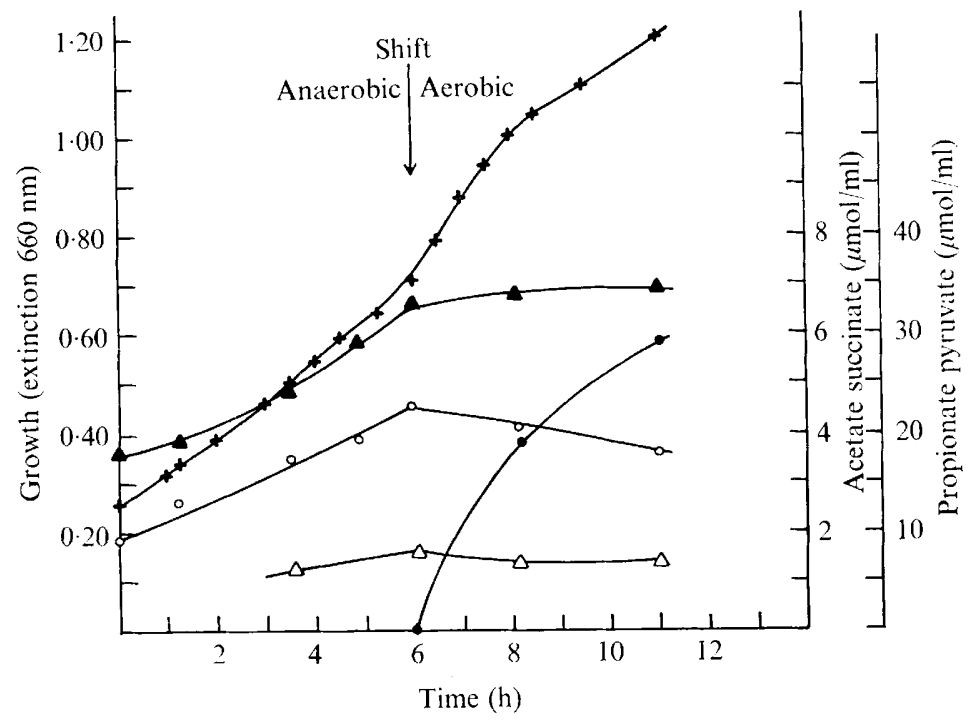

Fig. 4. Influence of a shift from anaerobic to aerobic conditions on growth and lactate metabolism of Propionibacterium freudenreichii. + , Growth; $\Delta$, acetate;,$O$, propionate; $i$, pyruvate; $\Delta$, succinate.

growth (Fig. $\mathrm{I} b$ ); during aerobic growth cytochrome synthesis was much slower than during anaerobic growth. Aerobic cytochrome synthesis was less repressed as the extinction of the culture was higher (Fig. I $b$ ).

Propionibacterium shermanii, $P$. rubrum and $P$. pentosaceum also contained cytochrome $b$, cytochrome $a$ (or $a_{1}$ ), cytochrome $a_{2}$ and a carbon monoxide-binding pigment. In these species cytochrome synthesis was followed during anaerobic and aerobic growth as with $P$. freudenreichii (Table $\mathrm{I}$ ). All four strains grew anaerobically with about the same rate (Table I). Aerobic growth of $P$. shermanii, like that of $P$. freudenreichii, was much slower than anaerobic growth and cytochrome synthesis was greatly diminished under aerobic conditions; $P$. rubrum and $P$. pentosaceum grew aerobically somewhat faster than anaerobically and cytochrome synthesis was less inhibited by aeration than in $P$. freudenreichii and $P$. shermanii (Table I). None of the species grew on agar plates under aerobic conditions. Our data on the aerobic growth rate of propionic acid bacteria agree with those of Breed et al. (1957) on the sensitivity of propionic acid bacteria to oxygen.

Bacteria often synthesize large amounts of intracellular polysaccharides under unfavourable growth conditions, and if this occurred during aerobic growth of Propionibacterium, the lowered cytochrome content, which was expressed on a dry weight basis, may be explained in this way. However, we found that the total polysaccharide content of Propionibacterium freudenreichii was the same after anaerobic and aerobic growth, namely I I \%, the normal percentage for the cell wall polysaccharides (Gunsalus \& Shuster, I96I). Therefore, the lowered cytochrome content of aerobic cells must indeed be ascribed to inhibition of cytochrome synthesis by oxygen.

\section{Energy generation under aerobic conditions}

To elucidate how propionic acid bacteria get energy during aerobic growth in liquid cultures experiments were carried out in which anaerobic cultures were shifted to aerobic conditions. Fermentation products were determined before and after the shift (Fig. 4). 


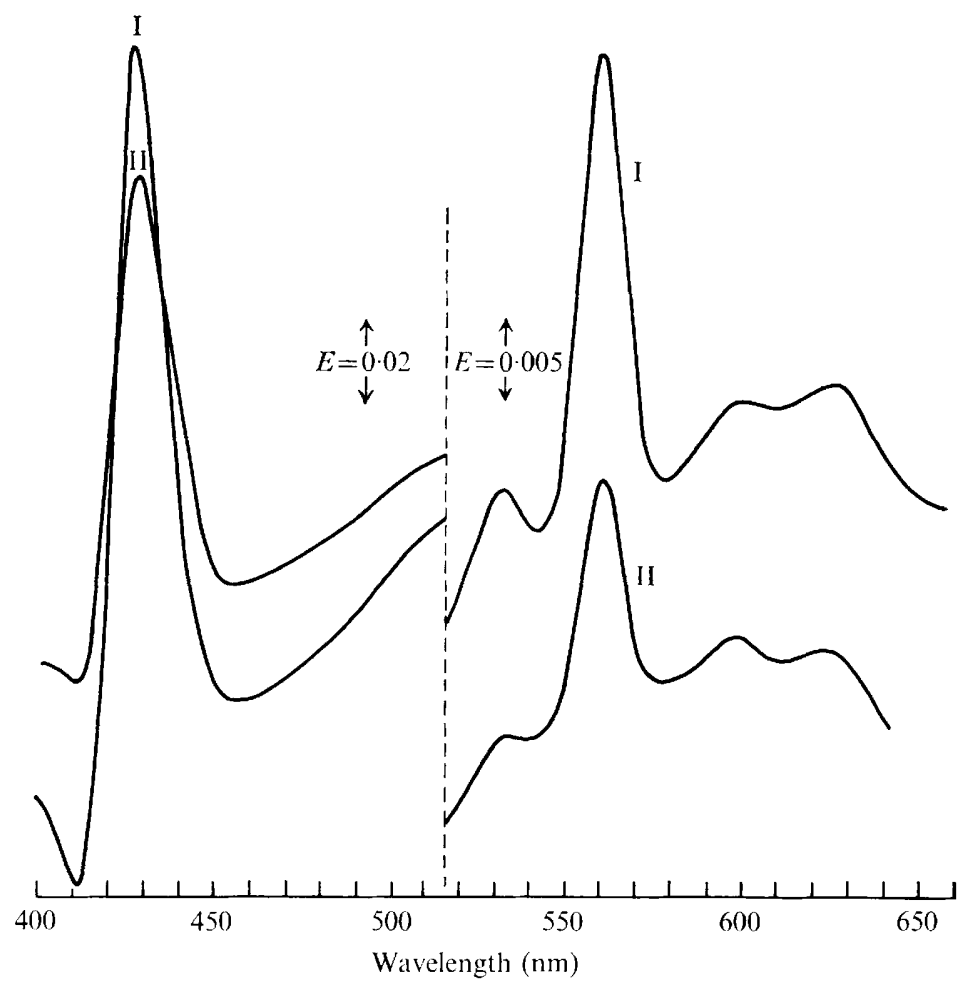

Fig. 5. Re-oxidation of cytochrome $b$ and $a_{2}$ of Propionibacterium freudenreichii by fumarate. I, lactate-reduced minus oxygen-oxidized difference spectrum; II, difference spectrum after addition of fumarate to the lactate-reduced cell suspension of $\mathrm{I}$.

Table_2.' Determination of $Y_{\mathrm{o}}$ for Propionibacterium freudenreichii

\begin{tabular}{|c|c|c|c|c|c|c|c|}
\hline & \multirow{2}{*}{$\begin{array}{c}\text { Extinction } \\
(660 \mathrm{~nm})\end{array}$} & \multirow{2}{*}{$\begin{array}{c}\text { Dry } \\
\text { weight* } \\
(\mu \mathrm{g} / \mathrm{ml})\end{array}$} & \multicolumn{3}{|c|}{ Products $(\mu \mathrm{mol} / \mathrm{ml})$} & \multirow{2}{*}{$\begin{array}{c}\text { Oxygen } \\
\text { uptake } \\
(\mu \mathrm{mol} / \mathrm{ml})\end{array}$} & \multirow{2}{*}{$\begin{array}{c}Y_{0} \\
\text { (g/g-atom) }\end{array}$} \\
\hline & & & Acetate & Propionate & Succinate & & \\
\hline 3efo & $0.4 \mathrm{I}$ & I64 & $2 \cdot 4$ & $5 \cdot 5$ & $I \cdot 2$ & - & - \\
\hline fter aerobic growth & 0.57 & 228 & $1 \cdot 5$ & $6 \cdot 0$ & 0.9 & 2.I & I5 \\
\hline
\end{tabular}

Immediately after the shift growth of Propionibacterium freudenreichii was somewhat faster than under anaerobic conditions (Fig. 4). The same phenomenon can be observed in Fig. I (a). Large amounts of pyruvate accumulated after the shift, whereas propionate formation ceased. Both before and after the shift only minor amounts of succinate were present (Fig. 4). Experiments with other strains yielded similar results. The data indicate that the bacteria get no energy from substrate-level phosphorylation under aerobic conditions.

For Propionibacterium freudenreichii the $Y_{0}$ value was determined in the basal medium with no glucose or lactate added. In this medium the culture grew anaerobically to an extinction of about $\mathbf{0 . 4 2}$. Apparently, at this point all fermentable compounds were exhausted from the medium. The culture was then shifted to aerobic conditions and oxygen uptake was followed. Again, the acetate, propionate and succinate contents of the culture were about the same before and after aerobic incubation (Table 2) indicating the absence of 
substrate level phosphorylation. Therefore the $Y_{0}$ value could be calculated as $15 \mathrm{~g}$ dry wt bacteria/g-atom of $\mathrm{O}$. Two other experiments with $P$. freudenreichii yielded $Y_{\mathrm{o}}$ values of I4 and $17 \mathrm{~g} / \mathrm{g}$-atom.

Function of cytochrome $b$ in anaerobic electron transport from lactate to fumarate

The observation that addition of fumarate to lactate-reduced suspensions of Propionibacterium freudenreichii resulted in partial oxidation of cytochrome $b$ and $a_{2}$ (Fig. 5) indicates a possible role of cytochrome $b$ in the electron transport chain from lactate to fumarate. Therefore, the influence of HOQNO, an inhibitor of cytochrome $b$ function, on the specific activity of lactate dehydrogenase in the presence of different $\mathrm{H}$-acceptors was studied. Just as previously found for the lactate dehydrogenase of $P$. pentosaceum (Molinari \& Lara, I960), the enzyme of $P$. freudenreichii did not react with NAD. However, a lactate dehydrogenase catalysing the reduction of fumarate and methylene blue was detected with specific activities of $72 \mathrm{nmol}$ pyruvate formed $/ \mathrm{mg}$ protein/min and $0.21 \mu \mathrm{mol} \mathrm{O}_{2}$ taken $\mathrm{up} / \mathrm{mg}$ protein $/ \mathrm{min}$, respectively. With fumarate as a $\mathrm{H}$-acceptor the enzyme was $85 \%$ inhibited by HOQNO. With methylene blue, which accepts $\mathrm{H}$-equivalents from flavoproteins without intervention of cytochromes (Quastel, I957), inhibition was only $25 \%$.

\section{DISCUSSION}

Four Propionibacterium strains examined contained cytochrome $b$, cytochrome $a$ or $a_{1}$, cytochrome $a_{2}$ and a carbon monoxide-binding pigment. Fumarate oxidized cytochrome $b$ and $a_{2}$ in Propionibacterium freudenreichii. Because the oxidation-reduction potential of cytochrome $a_{2}$ is presumably rather high, its oxidation by fumarate might be an indirect effect. Experiments with HOQNO, known as an inhibitor of cytochrome $b$ function (Cox et al. 1970), indicate that cytochrome $b$ functions directly in anaerobic electron transport from lactate to fumarate. To our knowledge little attention has been paid to the presence and function of cytochromes in anaerobic fermentative bacteria. Cytochromes were found in Bacteroides ruminicola and B. melaninogenicus after growth in the presence of haem, an essential growth factor. In these organisms, fumarate oxidized cytochrome $b$ and cytochrome $c$ respectively (White, Bryant \& Caldwell, 1962; Rizza, Sinclair, White \& Cuorant, I968). The conclusion that cytochrome $b$ functions in anaerobic electron transport to fumarate supports the suggestion of Bauchop \& Elsden (1960) that oxidative phosphorylation occurs during reduction of fumarate to succinate in the fermentation pathway of propionic acid bacteria.

Our manometric experiments with Propionibacterium freudenreichii and those of Delwiche \& Carson (1953) with $P$. pentosaceum indicate that a citric acid cycle is present in propionic acid bacteria. The presence of cytochromes and the citric acid cycle are typical of aerobic metabolism with energy generated by oxidative phosphorylation. Indeed, our growth experiments with propionic acid bacteria indicate that oxidative phosphorylation is the only way of getting energy during aerobic growth. From three manometric experiments a mean $Y_{\mathrm{o}}$ value of I 5 was calculated for $P$. freudenreichii. $Y_{\mathrm{ATP}}$ values (g dry wt of bacteria/mol of ATP) found for different micro-organisms vary from 8 to 20 (Forrest \& Walker, 197I). Therefore the $\mathrm{P} / \mathrm{O}$ ratio must be $\mathrm{I}$ to 2 for $P$. freudenreichii.

Cytochrome synthesis in propionic acid bacteria is impaired by oxygen. This also occurs in Haemophilus parainfluenzae and Spirillum itersonii (Clark-Walker, Rittenberg \& Lascelles, 1967; Sinclair \& White, 1970). If $\Delta$-amino-levulinic synthetase and $\Delta$-amino-levulinic 
dehydratase are repressed under aerobic conditions, as they are in Propionibacterium shermanii (Menon \& Shemin, 1967), then this would explain our observations.

In Propionibacterium freudenreichii and $P$. shermanii, which grew more slowly in aerated cultures than $P$. pentosaceum and $P$. rubrum, cytochrome synthesis was more repressed indicating a higher sensitivity to oxygen. Preliminary experiments (unpublished results) indicate that growth and cytochrome synthesis in $P$. freudenreichii are more strongly inhibited when the aeration is increased. We suppose that cytochrome synthesis in propionic acid bacteria is completely inhibited at high oxygen tensions, to which they are exposed when they are incubated on agar plates in air. Then, the ability of oxidative phosphorylation is lost and growth stops after a few division cycles. This may explain the inability of propionic acid bacteria to form colonies on plates incubated under aerobic conditions. More information on the influence of oxygen on cytochrome synthesis in propionic acid bacteria from cultures grown under controlled oxygen tension is being sought.

We thank Professor Dr K. W. Gerritsma for allowing us to use the gas chromatograph in the Laboratory of Analytical Chemistry, Free University, Amsterdam. We are extremely grateful to Dr H. van der Veen for his valuable advices on the gas chromatographic analyses. We thank Ir. F.F.J. Nieuwenhof (N.I.Z.O., Ede, The Netherlands) and Ir. J. van der Toorn (Technische Hogeschool, Delft, The Netherlands) for the cultures of propionibacteria.

\section{REFERENCES}

Allen, S. H. G., Kellermeyer, R. W., Stjernholm, R. L. \& Wood, H. G. (1964). Purification and properties of enzymes involved in the propionic acid fermentation. Journal of Bacteriology 87, I7I-187.

BARKER, H. A. \& LipMANN, F. (I944). On lactic acid metabolism in propionic acid bacteria and the problem of oxidation-reduction in the system fatty-hydroxy-keto acid. Archives of Biochemistry 4, 36I-370.

BAUCHOP, T. \& ElSDEN, S. R. (1960). The growth of micro-organisms in relation to their energy supply. Journal of General Microbiology 23, 457-469.

Breed, R. S., Murray, E. G. D. \& Smith, N. R. (1957). Bergey's Manual of Determinative Bacteriology, 7th edn. London: Baillière, Tindall \& Cox.

Cato, E. P., Cummins, C. S., Holdeman, L. V., Johnson, J. L., Moore, W. E. C., Smibert, R. M. \& Smith, L. D.S. (1970). Outline of Clinical Methods in Anaerobic Bacteriology. Blacksburg, Virginia; Virginia Polytechnic Institute and State University.

Chatx, P. \& Fromageot, C. (1942). Les cytochromes de Propionibacterium pentosaceum. Bulletin Social chimique et biologique 24, I125-1 127.

Clark-Walker, G. D., RitTenberg, B. \& Lascelles, J. (1967). Cytochrome synthesis and its regulation in Spirillum itersonii. Journal of Bacteriology 94, I648-I655.

Cox, G. B., Newton, N. A., Gibson, F., Snoswell, A. M. \& Hamilton, J. A. (1970). The function of ubiquinone in Escherichia coli. Biochemical Journal $\mathbf{1 1 7}, 55 \mathrm{I}-562$.

DeEB, S. S. \& HAGER, L. P. (1964). Crystalline cytochrome $b_{1}$ from Escherichia coli. Journal of Biological Chemistry 239, I024-103I.

Delwiche, E. A. \& Carson, S. F. (1953). A citric acid cycle in Propionibacterium pentosaceum. Journal of Bacteriology 65, 318-321.

FORREST, W. W. \& WALKER, D. J. (1971). The generation and utilization of energy during growth. In Advances in Microbial Physiology, vol. 5, pp. 213-274. Edited by A. H. Rose \& J. F. Wilkinson. New York and London: Academic Press.

Friedemann, T. E. \& Haugen, G. E. (1943). Pyruvic acid. II. The determination of keto acids in blood and urine. Journal of Biological Chemistry I47, 415-442.

Gunsalus, I. C. \& Shuster, C. W. (196I). Energy yielding metabolism in bacteria. In The Bacteria, vol. 2, Metabolism, pp. I-58. Edited by I. C. Gunsalus \& R. Y. Stanier. New York and London: Academic Press.

LARA, F. J. S. (1959). The succinic dehydrogenase of Propionibacterium pentosaceum. Biochimica et biophysicc acta 33, 565-567. 
524 W. DE VRIES, W. M. C. VAN WIJCK-KAPTEIJN AND A. H. STOUTHAMER

LipmanN, F. \& TUtTLE, L. C. (I945). A specific micromethod for the determination of acyl-phosphates. Journal of Biological Chemistry 159, $2 \mathrm{I}-28$.

Lowry, O. H., Rosebrough, N. J., Farr, A. L. \& Randall, R. J. (I95I). Protein measurement with the Folin phenol reagent. Journal of Biological Chemistry x93, 265-275.

Menon, J. A. \& SHemin, D. (1967). Concurrent decrease of enzymic activities concerned with the synthesis of coenzyme $\mathrm{B}_{12}$ and of propionic acid in Propionibacteria. Archives of Biochemistry and Biophysics 121, 304-310.

Molinari, R. \& Lara, F. J. S. (I960). The lactic dehydrogenase of Propionibacterium pentosaceum. Biochemical Journal 75, 57-65.

QuASTEL, J. H. (1957). Use of artificial electron acceptors in the study of dehydrogenases. In Methods in Enzymology, vol. IV, pp. 329-336. Edited by S. P. Colowick \& N. O. Kaplan. New York and London: Academic Press.

ReEkers, A. (1964). On the Production of a-Ketoglutaric Acid by Pseudomonas reptilivora Caldwell et Ryerson. Thesis, Technische Hogeschool, Delft, The Netherlands.

Rizza, V., Sinclair, P. R., White, D. C. \& Cuorant, P. R. (1968). Electron transport system of the protoheme requiring anaerobe $B$. melaninogenicus. Journal of Bacteriology 96, 665-67I.

Rose, I. A., Grunberg-Manago, M., Korey, S. R. \& OchoA, S. (1954). Enzymatic phosphorylation of acetate. Journal of Biological Chemistry 21x, 737-756.

Sinclair, P. R. \& Whrre, D. C. (1970). Effect of nitrate, fumarate and oxygen on the formation of the membrane bound electron transport system of Haemophilus parainfluenzae. Journal of Bacteriology Ior, $365-372$.

Trevelyan, W. E. \& Harrison, J. S. (1952). Studies on yeast metabolism. I. Fractionating and microdete $r$ mination of cell carbohydrates. Biochemical Journal 5o, 298-303.

De VRies, W. \& Stouthamer, A. H. (1968). Fermentation of glucose, lactose, galactose, mannitol and xylose by bifidobacteria. Journal of Bacteriology 96, 472-478.

White, D. C., Bryant, M. P. \& Caldwell, D. R. (1962). Cytochrome-linked fermentation in Bacteroïdsruminicola. Journal of Bacteriology 84, 822-828. 